\title{
Corrosion behavior of superhydrophobic film fabricated on AZ31B magnesium alloy by one-step immersion process in $\mathrm{NaCl}$ aqueous solution
}

\author{
Yuta SHIMADA*, Mika TSUNAKAWA*, Tetsuya YOKOMIZO* \\ Hoonseung LEE* and Takahiro ISHIZAKI**
}

Superhydrophobic film was prepared on magnesium alloy AZ31B by one-step immersion process for $30 \mathrm{~min}$. The solution for immersion process was composed of an aqueous solution containing $\mathrm{Ce}\left(\mathrm{NO}_{3}\right)_{3}$ and ethanol containing myristic acid. The water contact angle of the prepared film was more than 150 degree and found to be superhydrophobic. The film was composed mainly of crystalline myristic acid. The corrosion behavior of the superhydrophobic film in 5 mass $\% \mathrm{NaCl}$ aqueous solution were investigated by polarization curve. The corrosion resistance was considerably improved by preparing the superhydrophobic film. In addition, the corrosion process of the superhydrophobic AZ31B was also investigated using XRD, SEM, and water contact angle measurement.

(Received May 22, 2017 Accepted October 15, 2017)

Keywords: magnesium alloy; superhydrophobicity; corrosion behavior; immersion process

\section{1. 緒言}

マグネシウムは地殼構成クラーク数が 8 番目でその地殼表 層部における存在重量比は約 2 mass\%であり, 資源も豊富な 元素である1。このため, 今後の使用量を増やすことが可能 であり，その用途拡大を行うべき材料である。マグネシウム は人体に無害であるため生体材料，また，その物理的特性か ら振動吸収性や電磁シールド性に富むため, 家庭用電気機械 器具や電子機器への応用が期待されている ${ }^{2), 3)}$ 。さらに, そ の比重が 1.72 と鉄の $1 / 4$ ，アルミニウムの $2 / 3$ であり，実用金 属中において最軽量であるため, 軽量性を求める材料の代替 となり得る。マグネシウム合金は，マグネシウムに異種元素 を微量添加した高比強度の軽量合金であり, リサイクル性に 優れる。このような優れた性質を有するマグネシウム合金で あるが，その普及が遅れており，広範囲に使用されるには 至っていない。この理由としては, 加工性の悪さ, 燃焼のし やすさ等の問題が挙(゙られる ${ }^{4), 5)}$ 。加工性においては, マグ ネシウムの結晶構造は最密六方晶であり，すべり系が底面に
限定されるために, 顕著な加工集合組織が発達し, 塑性異方 性を有する。このため, 常温での塑性加工性が悪〈なる ${ }^{5), 6) 。 ~}$ また，燃焼性においては，金属が活性であるため，粉体化す ると燃えやすいという欠点を有している。大気中で加熱する と, 微粉末では $673 \mathrm{~K}$ 以上, インゴットでは $923 \mathrm{~K}$ 以上で融 解し, 発火する。このため, 大気中での溶解, 鋳造が困難で あり, 大気との接触を防ぐための六フッ化硫黄 $\left(\mathrm{SF}_{6}\right)$ ガス が必須となっている。このガスはオゾン層を破壊するガスと して指定されており，近年ではこのガスを用いないで，溶 解・鋳造が可能となる, カルシウムが合金に添加された難燃

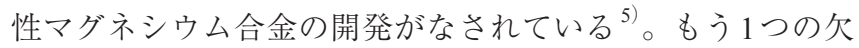
点として，マグネシウムが有する化学的活性のため, その耐 食性の低さが挙げられる。この欠点を克服するために, 陽極 酸化処理や化成処理等を中心とした表面処理法が開発されて (る ${ }^{7), 8)}$ 。陽極酸化処理や化成処理では，使用する浴にフッ 化物や重金属であるクロム酸やマンガン酸塩を含むものが多 く, 環境負荷が高くなる傾向がある。また, これらのプロセ スでは, 多段階の前処理が必要であり, コスト増につながる。

*芝浦工業大学大学院理工学研究科材料工学専攻（† 135-8548 東京都江東区豊洲3-7-5） Materials Science and Engineering, Graduate School of Engineering and Science, Shibaura Institute of Technology (3-7-5 Toyosu, Koto-ku, Tokyo 135-8548)

**芝浦工業大学工学部材料工学科 (東京都) Department of Materials Science and Engineering, College of Engineering, Shibaura Institute of Technology

(Koto-ku, Tokyo) E-mail: ishizaki@shibaura-it.ac.jp 
このため, 低環境負荷型で低コストの新規表面処理の開発が 強く望まれている ${ }^{9), 10)}$

近年，マグネシウム合金の耐食性を改善するための表面処 理方法として, 超はっ水処理の適用が報告されている。超 はっ水とは接触角が $150^{\circ}$ 以上を示す現象であり ${ }^{11)}$, 接触角 は，液滴を材料表面に滴下した際の，固体，液体，気体が互 いに接触する境界において, 液相と固相の境界面が, 液相と 気相の境界面（水滴表面）と作る角度として定義される。超 はっ水表面を形成するためには，2つの因子を制御する必要 がある。1つは化学的な因子であり, もう1つは形状的因子 である。化学的因子とは材料表面の表面エネルギーであり, 形状的因子とは材料表面の実表面積である。材料表面の表面 エネルギーを小さくし実表面積を大きくすることにより, 超 はっ水表面の作製が可能になる ${ }^{12)}$ 。超はっ水処理を施すこと で，水分とマグネシウム合金の接触を抑制することができる ため, 水分との接触を介して進行する腐食反応を低減させる ことが可能である。例えば, マグネシウム合金への超はっ水 処理により，耐食性が向上することが報告されている ${ }^{13), 14) 。 ~}$ 従来の超はっ水処理は2つの因子を制御するために多段階処 理が行われているが，処理時間が数時間程度必要となる点が 課題である。超はっ水性を産業的に展開させるためには，工 程数を減らし，その処理時間を短くする必要がある。このよ うな背景の下, 我々のグループでは, 短時間（～30分）か つ1プロセスで超はっ水処理を行うための技術開発を行い, マグネシウム合金に超はっ水表面を形成するためのプロセス

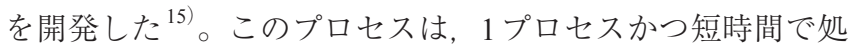
理できるため，低コストである。さらに，処理溶液の量を少 なくすることができるため, 低環境負荷型のプロセスである と考えられ，産業的な観点から有益である。また，本プロセ スでは，腐食抑制剤として機能するセリウム源を利用して超 はっ水皮膜を形成するため, 従来の超はっ水処理よりも耐食 性のさらなる向上が期待できる ${ }^{16)}$ 。しかし，本プロセスで 形成した超はっ水皮膜を被覆したマグネシウム合金の塩水中 での腐食挙動の詳細に関しては未検討である。本研究では, マグネシウム合金上に形成した超はっ水皮膜の化学的特性と 塩水中での耐食性を調査し, 超はっ水皮膜の塩水中での腐食 挙動を明らかにすることを目的とした。

\section{2. 実 験方法}

基材には，マグネシウム合金 AZ31Bの圧延材を用いた。 $\mathrm{AZ31B}$ の添加元素は, $\mathrm{Al}, \mathrm{Zn}, \mathrm{Mn}, \mathrm{Si}, \mathrm{Cu}, \mathrm{Ni}, \mathrm{Fe}$ であり, これら の元素の添加量はそれぞれ $2.98 \mathrm{mass} \%, 0.88 \mathrm{mass} \%, 0.38 \mathrm{mass} \%$, $0.0135 \mathrm{mass} \%, 0.001 \mathrm{mass} \%, 0.002 \mathrm{mass} \%, 0.0027 \mathrm{mass} \%$ ある。 $20 \mathrm{~mm} \times 20 \mathrm{~mm} \times 2 \mathrm{~mm}$ あるいは $10 \mathrm{~mm} \times 10 \mathrm{~mm} \times 2 \mathrm{~mm}$ に切断し たAZ31Bをエタノール（純度 $99.5 \%$ ）中に入れ，10 minの超 音波洗浄を行うことにより，表面の不純物を除去した。洗浄 後は, 窒素ガス（純度 $99.5 \%$ ）を吹き付けて乾燥させた。超 はっ水皮膜を形成するための試薬として, 硝酸セリウム六水 和物 $\left(\mathrm{Ce}\left(\mathrm{NO}_{3}\right)_{3} \cdot 6 \mathrm{H}_{2} \mathrm{O}\right)$ とミリスチン酸 $\left(\mathrm{C}_{14} \mathrm{H}_{28} \mathrm{O}_{2}\right)$ を用い た ${ }^{15)}$ 。100 mLの超純水中に硝酸セリウム（1.15g) を添加し て撹拌し, 溶液 Aとした。一方, $100 \mathrm{~mL}$ のエタノールにミリ スチン酸（5.13g）を添加し擋拌したものを溶液 B とした。溶 液 $\mathrm{A}$ と B 体積比 $3: 7$ の割合で混合した溶液を $\mathrm{pH}=2$ に調整し た。 $\mathrm{pH}$ の調整には $0.5 \mathrm{~mol} / \mathrm{L}$ （以下 $\mathrm{M}$ と略記）の硝酸水溶液を
使用した。調整した混合水溶液中に洗浄したAZ31Bを室温下 で $30 \mathrm{~min}$ 浸漬させることにより, 超はっ水処理を行った。そ の後, 超はっ水処理後の AZ31Bをエタノールで洗浄した。

超はっ水処理後のAZ31Bの濡れ性を評価するために, 水 滴接触角計を用いて表面の静的接触角を測定した。接触角測 定の液滴プローブには超純水（抵抗率： $18.2 \mathrm{M} \Omega \cdot \mathrm{cm}$ ）を使 用した。皮膜表面に滴下した $5 \mu \mathrm{L}$ の水滴の接触角を測定し た。すべての水滴接触角測定は室温で行った。

超はっ水皮膜表面を走査型電子顕微鏡 (Scanning Electron Microscope: SEM ; 日本電子株式会社製JSM6010LA）で観察 した。観察条件は加速電圧を $20 \mathrm{kV}, \mathrm{WD}$ (Working distance) を $12 \mathrm{~mm}$ とした。X線光電子分光 (X-ray Photoelectron Spectroscopy: XPS；日本電子株式会社製JPS-9010MC）を用 いて元素分析を行った。線源には $\mathrm{MgK} \alpha$ を用い, 加速電圧は $10 \mathrm{kV}$ ，電流は $25 \mathrm{~mA}$ に設定し測定した。作製した皮膜の結 晶相はX線回折装置 (X-ray diffraction: XRD; 株式会社リガ ク製Ultima IV, $40 \mathrm{kV}, 40 \mathrm{~mA}$ ）を用いて解析した。XRDの線 源にはCuk $\alpha$ 線を用いた。

耐食性の評価には, 分極試験と塩水浸漬試験を用いた。溶 液には, $5 \mathrm{mass} \% \mathrm{NaCl}$ 水溶液を用いた。分極試験は, 三電極 式電解セルを用いて室温で行った。作用極には超はっ水処理し た AZ31B, 対極には Ptメッシュ, 参照極には飽和 $\mathrm{Ag} / \mathrm{AgCl}$ 電 極を用いた。 $5 \mathrm{mass} \% \mathrm{NaCl}$ 水溶液中に AZ31Bを浸漬させた状 態で $30 \mathrm{~min}$ 保持し, 自然電位測定を行った。その後, 電位の掃 引速度は $0.5 \mathrm{mV} / \mathrm{s}$ とし, 掃引範囲は腐食電位に対して $-100 \mathrm{mV}$ から $+800 \mathrm{mV}$ として分極曲線を得た。塩水浸漬試験は $308 \mathrm{~K} の$ $5 \mathrm{mass} \% \mathrm{NaCl}$ 水溶液に $0.5 \sim 24 \mathrm{~h}$ 浸漬させ, 浸漬後の皮膜表面 をSEMで観察し, XRDで構造解析を行った。なお, 本研究で 用いた $\mathrm{NaCl}$ 水溶液はすべて大気開放状態で使用した。

\section{3. 実験結果および考察}

\section{1 超はつ水表面の作製}

混合水溶液に $30 \mathrm{~min}$ 浸漬させて作製した皮膜表面のSEM 像をFig. 1 (a) に示す。また, 静的接触角を計測した際の液 滴の形状をFig. 1 (a) の挿入図として併せて示す。混合水溶 (a)

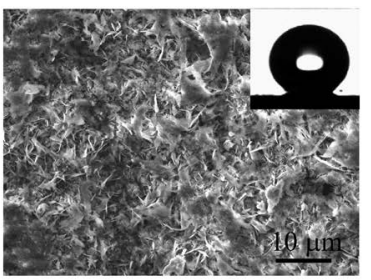

(c)

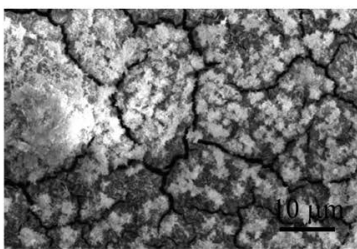

(b)

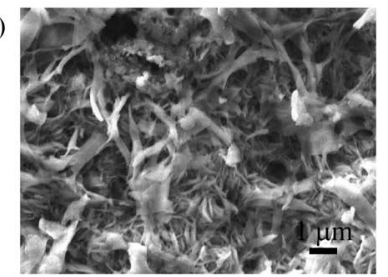

(d)

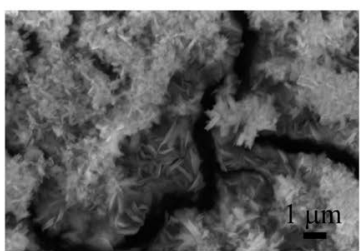

Fig. 1 (a) SEM image of superhydrophobic surface fabricated on AZ31B magnesium alloy. Inset shows the shape of water droplet on the superhydrophobic AZ31B magnesium alloy surface. (b) SEM image of enlarged version of Fig. 1(a). (c) SEM image of superhydrophobic surface at a point different from the one indicated in Fig. 1(a). (d) SEM image of enlarged version of Fig. 1(c). 
(a)
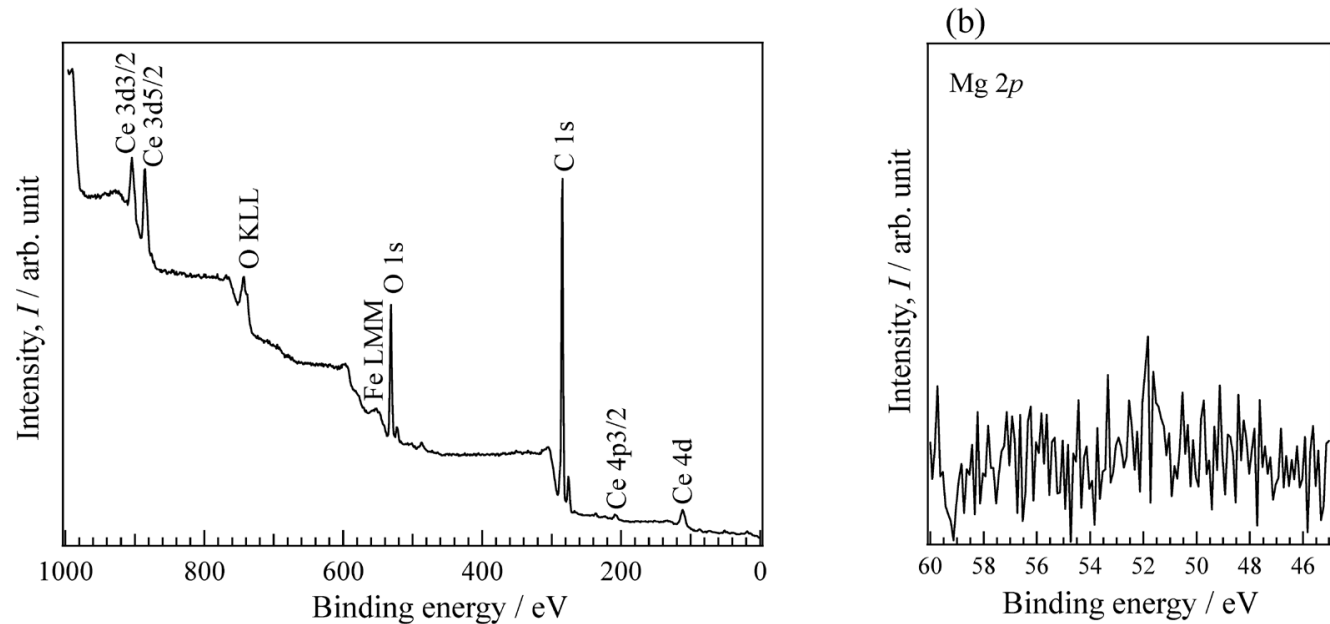

Fig. 2 (a) XPS wide and (b) $\mathrm{Mg} 2 p$ spectra of superhydrophobic surface fabricated on AZ31B magnesium alloy.

液に浸漬させることにより, AZ31B表面には皮膜が形成さ れていた。また，その皮膜表面には，微細な針状物質や小さ いポアが存在しており，粗い表面であることがわかる。Fig. 1（b）にFig. 1 (a) の拡大SEM像を示す。Fig. 1(b) から，表 面には微細な粒状物質, サブミクロンスケールの針状物質, サブミクロン〜数マイクロメートルスケールの不定形の物質 等が形成されており，凹凸構造を有する表面であった。また， Fig. 1(c) に，皮膜表面において，Fig. 1(a) とは異なる位置 のSEM像を示す。Fig. 1 (c) のような表面形状は皮膜表面上 でわずかに観察された。その皮膜表面には，微細な針状物質 や数マイクロメートルスケールの粒状物質が生成していた。 Fig. 1 (d) にFig. 1(c) の拡大 SEM像を示す。Fig. 1(d) の粒 状物質は，微細なサブミクロンスケールの板状物質の集合体 で形成されていた。これらの結果から，表面にはスケールの 異なる凹凸構造が形成されていることがわかる。この結果 は，超はっ水表面を作製するために必要な形状的因子を付与 できたことを示す。また，作製した表面は，Fig. 1の挿入図 に示すように, 水滴静的接触角が $150^{\circ}$ 以上になり, 超はっ水 性を示した。

X線光電子分光（XPS）を用いて超はっ水膜を被覆した表 面の元素分析を行った。Fig. 2(a) に皮膜表面のXPSワイド スペクトルを示す。結合エネルギーが 880～900, 120, $220 \mathrm{eV}$ 付近に, Ce $3 d, 4 d, 4 p$ 軌道に起因するピークがそれぞれ観察 された。一方, $\operatorname{Mg} 2 p$ に起因するピークの存在を明確に確認 することはできなかった。皮膜表面の $\mathrm{Mg}$ の存在を確認する ために, $\operatorname{Mg} 2 p$ のナロースペクトルの測定を行った。その結 果を Fig. 2(b) に示す。スペクトル中には明確なピークの存 在は確認できないが，51〜 $52 \mathrm{eV}$ 付近のスペクトルの強度が わずかに高いことから，Mg系化合物が皮膜表面近傍で微量 に存在したと考えられる。既報の結果から，本研究と同様の 手法で作製した皮膜中の Ceには3 価と4価の状態が共存して いる ${ }^{15)}$ 。硝酸セリウム水溶液にAZ31B を室温で浸漬させる と 4 価の $\mathrm{CeO}_{2}$ が形成されたことが報告されている ${ }^{17)}$ 。また, 硝酸セリウムを用いた化成処理により 3 価の $\mathrm{Ce}(\mathrm{OH})_{3}$ が形成 されたことが報告されている ${ }^{16)}$ 。3価の酸化物として, $\mathrm{CeO}_{2}$ が還元された $\mathrm{Ce}_{2} \mathrm{O}_{3}$ も存在する ${ }^{18)}$ 。しかし, $\mathrm{Ce}_{2} \mathrm{O}_{3}$ は酸素欠 損型の酸化物であり，大気中では準安定相であるため，酸 素の存在下では $\mathrm{CeO}_{2}$ になりやすい ${ }^{19)}$ 21)。これらの報告例
Table 1 Atomic composition of as-prepared superhydrophobic AZ31B magnesium alloy surface acquired by XPS measurement.

$(\mathrm{at} \%)$

\begin{tabular}{c|c|c|c}
\hline \hline $\mathrm{Ce}$ & $\mathrm{C}$ & $\mathrm{O}$ & $\mathrm{Mg}$ \\
\hline 1.8 & 82.9 & 14.6 & 0.7 \\
\hline
\end{tabular}

から，本研究においては， $\mathrm{Ce}(\mathrm{OH})_{3} や \mathrm{CeO}_{2}$ が形成されたと 考えられる。その他, $285 \mathrm{eV}$ 付近の C $1 \mathrm{~s}$ 軌道や $530 \mathrm{eV}$ 付近 のO $1 \mathrm{~s}$ 軌道に関するピークが存在した。これらの結果から， 皮膜表面には, ミリスチン酸, $\mathrm{Ce}(\mathrm{OH})_{3}, \mathrm{CeO}_{2}$ が混在して いると考えられる。Table 1 に, 作製した皮膜最表面の元素 分析の結果を示す。元素分析の結果, 皮膜最表面近傍におけ るCの原子濃度が $82.9 \%$ と非常に多かった。表面近傍のC濃 度が高くなったのは，ミリスチン酸が表面に多く存在したた めと考えられる。ミリスチン酸は末端に疎水基であるメチル 基 $\left(-\mathrm{CH}_{3}\right)$ と親水基であるカルボキシル基 $(-\mathrm{COOH})$ を有 する脂肪酸であり ${ }^{22)}$, メチレン基 $\left(-\mathrm{CH}_{2}\right)$ も分子骨格内に 多数有するため, 多くのC 原子を含有する。また，末端官能 基にカルボキシル基を有する有機分子は金属酸化物に吸着す

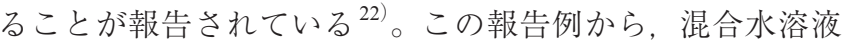
にAZ31Bを浸漬させることにより，末端の親水基であるカ ルボキシル基が溶液中の反応により形成された $\mathrm{Ce}(\mathrm{OH})_{3}$ や $\mathrm{CeO}_{2}$ に吸着したと考えられる。

Fig. 3 に皮膜被覆後の AZ31Bの XRD パターンを示す。 $2 \theta=6.1,8.4,10.9^{\circ}$ 付近にピークが存在し, これらのピークは 単斜晶系のミリスチン酸 $\left(\mathrm{C}_{14} \mathrm{H}_{28} \mathrm{O}_{2}\right)$ の $002,003,005$ 反射に 帰属した ${ }^{23)}$ 。また, $2 \theta=22.0$ 付近に, 単斜晶系のミリスチン 酸 $\left(\mathrm{C}_{14} \mathrm{H}_{28} \mathrm{O}_{2}\right)$ の 110 反射に起因するピークが存在した。ミ リスチン酸の分子鎖長はおよそ $1.4 \mathrm{~nm}$ であること，また， 002 反射の格子面間隔 $d$ が約 $0.7 \mathrm{~nm}$ であることを考えると, ミリスチン酸は c 軸方向に配向して吸着したと考えられる。 ミリスチン酸の分子間には疎水基の- $\mathrm{CH}_{2}$ 基が多く存在する ため，疎水性相互作用が分子間力として作用することが推察 される。この疎水性相互作用により, アルキル鎖の長い分子 は自己組織化し，緻密に配列することが報告されている ${ }^{24)}$ 。 本研究においても，ミリスチン酸が密に配列し，表面を被覆 したと考えられる。稲岡らは, ミリスチン酸と同様の構造で 


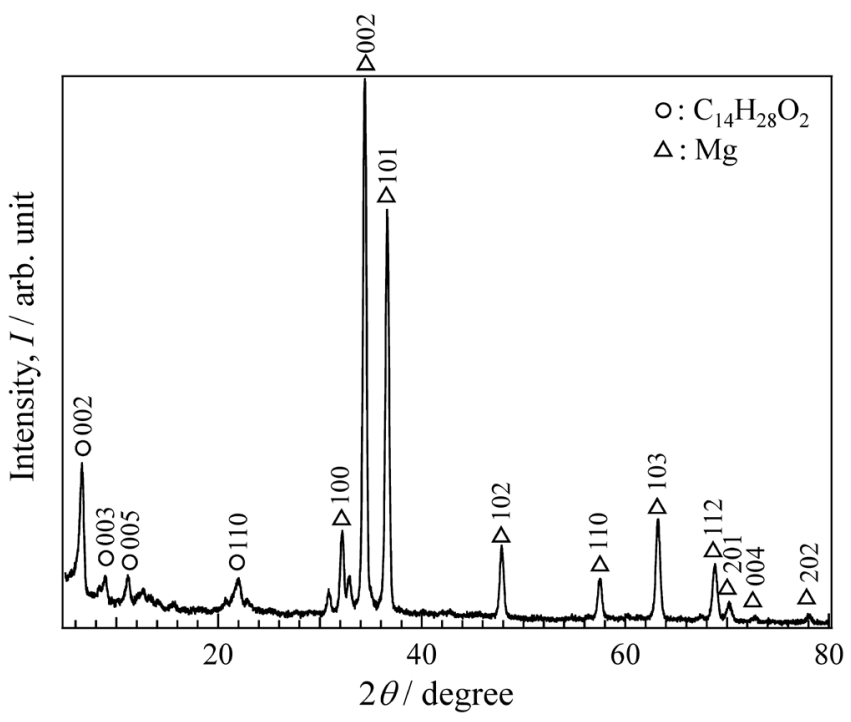

Fig. 3 XRD pattern of superhydrophobic film fabricated on AZ31B magnesium alloy.

アルキル鎖長がミリスチン酸より長いステアリン酸を用い た場合に，結晶性の固体層が形成されることを報告した ${ }^{25 ） 。 ~}$ この場合，アルキル鎖が基材に対して垂直方向から傾いて配 向していた。本研究においても，ミリスチン酸がステアリン 酸の場合と同様に結晶性の固体層になったと考えられる。一 方，XPSスペクトルから，Ceは3 価と4価の状態で存在して いた ${ }^{15)}$ 。これらの結果から, $\mathrm{Ce}(\mathrm{OH})_{3}$ や $\mathrm{CeO}_{2}$ が皮膜の最表 面に存在していたことがわかる。一方， Ceの原子濃度は低 いことから, これらの存在量は微量である。しかし, 皮膜 を被覆したAZ31BのXRDパターンからは, $\mathrm{Ce}(\mathrm{OH})_{3}$ や $\mathrm{CeO}_{2}$ に起因するピークは存在しなかった。これらの結果を総合的 に考えると, 皮膜の主成分はミリスチン酸の結晶性の固体 層であり，XPSで検出された $\mathrm{Ce}(\mathrm{OH})_{3}$ や $\mathrm{CeO}_{2}$ はアモルファ スあるいは微量成分であったと推察される。また，Fig. 1 の SEM 像, Fig. 2 のPS 結果, Fig. 3 のRD結果から, 皮膜の 厚みは $1 \mu \mathrm{m}$ 程度であると推察される。すなわち, 作製した 皮膜は, ミリスチン酸が基材に対して垂直方向に傾きを持っ て多層的に吸着している構造であり，メチル基同士では疎水 性相互作用による吸着が生じ，カルボキシル基同士では水素 結合による吸着が生じたと推察される。また, カルボキシル 基間の一部には, $\mathrm{Ce}(\mathrm{OH})_{3}, \mathrm{CeO}_{2}$ が存在している可能性も ある。これらの結果から考えられる皮膜の構造を Fig. 4 に示 す。この図からわかるように，表面エネルギーの小さいメ チル基 $\left(-\mathrm{CH}_{3}\right)$ が最表面に存在し，かつ凹凸構造を形成し ているため, 皮膜表面は超はっ水性を示したと考えられる。 Cassie と Baxter は, 接触角 $\alpha, \beta$ の 2 種類の材料が, 面積分率 $\mathrm{f}_{1}$ と $\mathrm{f}_{2}$ で構成する表面での接触角 $\theta$ は, 次式で与えられること を示した ${ }^{26)}$ (ここで, $\left.\mathrm{f}_{1}+\mathrm{f}_{2}=1\right)$ 。

$$
\cos \theta=\mathrm{f}_{1} \cos \alpha+\mathrm{f}_{2} \cos \beta
$$

この式は, Cassieの式と呼ばれる。空気は非常に濡れにく いため, 空気の接触角を $180^{\circ}$ と仮定すると， $\beta$ が $180^{\circ}$ とな り，(1)式より次式が求まる。

$$
\cos \theta=f_{1} \cos \alpha+\left(1-f_{1}\right) \times \cos \left(180^{\circ}\right)=f_{1}(1+\cos \alpha)-1
$$

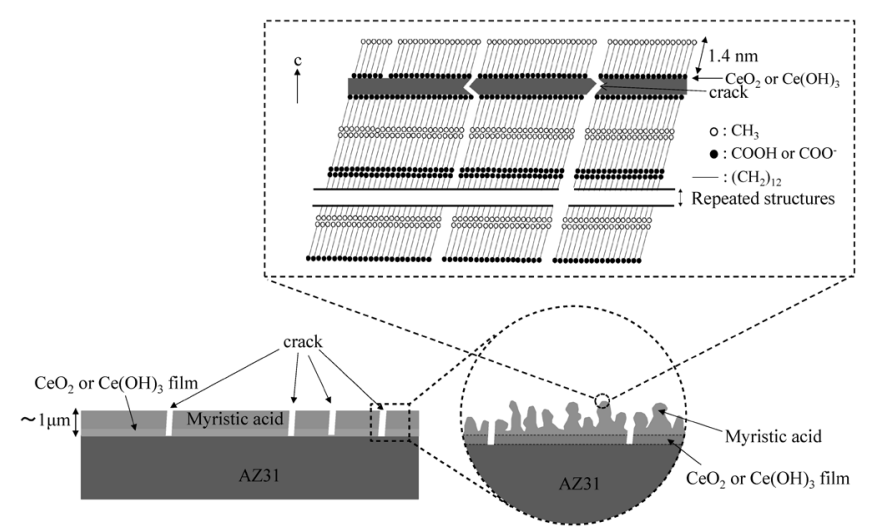

Fig. 4 Schematic illustration of film structure for the superhydrophobic AZ31B magnesium alloy surface.

$\mathrm{f}_{1}$ は固体と液体の接触界面の割合を, $\left(1-\mathrm{f}_{1}\right)$ は固体と気 体の接触界面の割合を意味し，ここでの気体は空気と考え る。この (2) 式より, 水滴と接触する材料表面において, $\mathrm{f}_{1}$ を小さくするとともに $\cos \alpha$ の值を小さくすれば $\cos \theta$ の值が -1 に近づくため，接触角 $\theta$ の值が大きくなることがわかる。 $\cos \alpha$ の值を小さくするためには，表面エネルギーの小さい材 料を表面に配置することで実現できる。 $\mathrm{f}_{1}$ を小さくるため には, 固体と液体と気体の界面に生じる三重線の長さを短く する必要がある 27)。このためには, 固体表面に一定重量の 液滴を着滴させた際の着液面の円周 (三重線) を短くするよ うな表面形状の作製が必要である ${ }^{28)}$ 。このような形状とし て, 空気の閉じ込めが可能な凹部と頂点面積の小さい凸部を 有する凹凸構造が挙げられ，針状構造がその代表例である。 したがって, 大きな実表面積になる針状の凹凸構造にするこ とで， $\mathrm{f}_{1}$ をさくすることが可能となる。これらの観点から， 超はっ水状態を実現するには, 三重線を短くするための実表 面積の大きな凹凸構造と表面エネルギーの小さい官能基を同 時に付与すればよいことがわかる。本研究で作製した皮膜も 表面に実表面積の大きな凹凸構造と表面エネルギーの小さい 官能基を有するミリスチン酸を付与したため, 超はっ水皮膜 が形成されたと考えられる。

\section{2 超はつ水処理を施したAZ31Bの分極試験}

超はっ水処理を施した AZ31Bの腐食挙動を調べるために, 5 mass $\% \mathrm{NaCl}$ 水溶液中において分極試験を行った。耐食性向 上に関して，セリウム系化合物，ミリスチン酸，あるいはそ の両方が寄与しているかを調べるために, セリウム系皮膜の みを被覆したAZ31Bの分極試験も行った。未処理のAZ31B, セリウム系皮膜および超はっ水皮膜を被覆したAZ31Bを用 いて得られた分極曲線を Fig. 5 (a)，(b)，(c) にそれぞれ示す。 また, これらの曲線からターフェル外挿法によって得られた 腐食電位， $E_{\text {corr }}$ および腐食電流密度， $i_{\text {corr }}$ を Table 2 に示す。 未処理の AZ31Bの場合, $E_{\text {corr }}$ は-1.49V vs. $\mathrm{Ag} / \mathrm{AgCl}, \quad i_{\text {corr }}$ は $3.46 \times 10^{-5} \mathrm{~A} \cdot \mathrm{cm}^{-2}$ であった。電位を $E_{\mathrm{corr}}$ よりもアノード方向 に掃引すると, 電流密度が急激に上昇し, $-1.3 \mathrm{~V} v \mathrm{~s} . \mathrm{Ag} / \mathrm{AgCl}$ 付近で電流值が一定となり, 限界電流的挙動を示した。一方, セリウム系皮膜のみを被覆した AZ31Bの $E_{\text {corr }}$ は- $0.71 \mathrm{~V} v s$. $\mathrm{Ag} / \mathrm{AgCl}, \quad i_{\text {corr }}$ は $2.00 \times 10^{-7} \mathrm{~A} \cdot \mathrm{cm}^{-2}$ であった。未処理の AZ31B と比較すると， $E_{\text {corr }}$ が約 $0.8 \mathrm{~V}$ 貴化し， $i_{\text {corr }}$ は約 2 桁低下した。 この結果から, セリウム系皮膜を被覆することで, 耐食性 


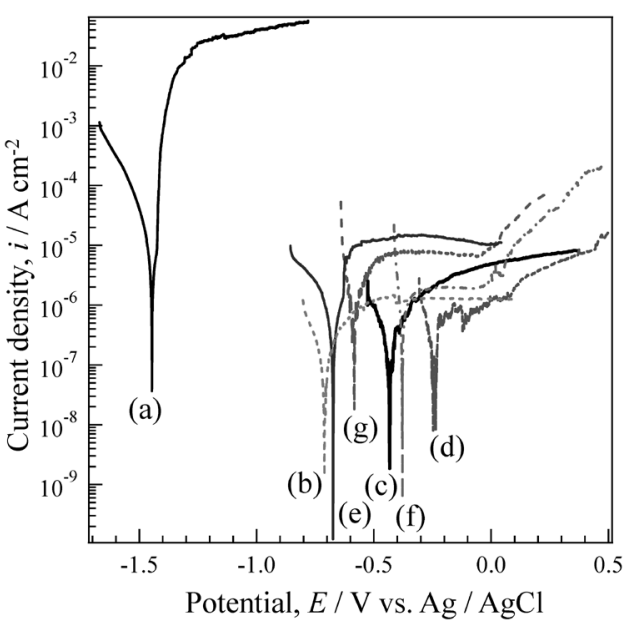

Fig. 5 Polarization curves of (a) untreated AZ31B magnesium alloy, (b) AZ31B coated with $\mathrm{CeO}_{2}$ and/or $\mathrm{Ce}(\mathrm{OH})_{3}$ film, and superhydrophobic AZ31B magnesium alloy (c) before and after immersion in 5 mass $\% \mathrm{NaCl}$ aqueous solution for (d) 1, (e) 6. (f) 12, and (g) $24 \mathrm{~h}$.

Table 2 Fitting results of the polarization curves obtained by Tafel extrapolation method.

\begin{tabular}{l|c|c}
\hline \hline & $\begin{array}{c}\text { Corrosion potential, } \\
E_{\text {corr }} / \mathrm{V} v s . \\
(\mathrm{Ag} / \mathrm{AgCl})\end{array}$ & $\begin{array}{c}\text { Corrosion current } \\
\text { density, } \\
i_{\text {corr }} /\left(\mathrm{A} \cdot \mathrm{cm}^{-2}\right)\end{array}$ \\
\hline $\mathrm{AZ31B}$ magnesium alloy & -1.49 & $3.46 \times 10^{-5}$ \\
\hline $\mathrm{CeO}_{2}$ and/or $\mathrm{Ce}(\mathrm{OH})_{3}$ film & -0.71 & $2.00 \times 10^{-7}$ \\
\hline Superhydrophobic $\mathrm{AZ31B}$ & -0.43 & $4.41 \times 10^{-7}$ \\
\hline
\end{tabular}

が向上したことがわかる。また, 超はっ水処理した AZ31B では， $E_{\text {corr }}$ は-0.43Vvs. Ag/ $\mathrm{AgCl}, \quad i_{\text {corr }}$ は $4.41 \times 10^{-7} \mathrm{~A} \cdot \mathrm{cm}^{-2}$ と なり，未処理の AZ31B と比較すると， $E_{\text {corr }}$ が約 $1.0 \mathrm{~V}$ 貴化し， $i_{\text {corr }}$ は約 2 桁低下した。一般に, 電流密度は反応速度に比例 することから， $i_{\text {corr }}$ の低下は，腐食反応速度の低下を示す。 また，セリウム系皮膜を被覆した $\mathrm{AZ31B}$ と比較すると， $E_{\text {corr }}$ が約 $0.3 \mathrm{~V}$ 貴化し， $i_{\text {corr }}$ はほとんど同じであった。この結果か ら， $i_{\text {corr }}$ に大きな影響を与えているのはセリウム系皮膜であ

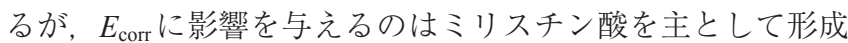
された皮膜とセリウム系化合物からなる皮膜の相乗効果によ るものであると考えられ，この相乗効果が耐食性の向上に 関して有効であることがわかる。また，超はっ水処理した

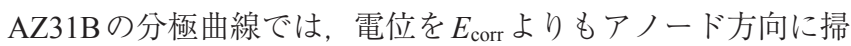
引すると, $-0.2 \mathrm{~V} v \mathrm{~s} . \mathrm{Ag} / \mathrm{AgCl}$ 付近で電流密度の值が一定と なり，限界電流的挙動を示した。超はっ水処理した AZ31B の $E_{\text {corr }}$ よりもアノード領域におけるアノード電流密度を未処 理の AZ31Bでの值と比較すると，皮膜のある試料の方が低 い值であった。この結果から, 超はっ水皮膜の形成により, アノード電流密度が抑制されたことがわかる。これらの結果 は，超はっ水皮膜を形成させたことにより耐食性が向上した ことを示す。耐食性向上の理由の一つとして，セリウム系の 酸化物あるいは水酸化皮膜の形成が寄与していると考えられ る。セリウム源を用いた化成処理では，セリウム系の酸化物 や水酸化物の皮膜が形成されるため，セリウムは腐食抑制剂
として機能することが知られている ${ }^{16)}$ 。本研究においても, 使用したセリウム源からセリウム系の酸化物や水酸化物の皮 膜がAZ31B上に形成されたとともに, 皮膜内にも含有され ていたことから，これらが腐食抑制剂として機能した可能性 もあり得る ${ }^{16)}$ 。しかし，XPSの結果から，皮膜最表面に含ま れるセリウム系の酸化物や水酸化物の存在量は微量であるた め，その腐食抑制作用は極めて小さかったと推察される。も うひとつの理由としては, ミリスチン酸分子の吸着と凹凸構 造の付与による超はっ水性の発現が考えられる。メチル基を 末端に有するシリカ系皮膜を AZ31Bに被覆して作製した超 はっ水表面では，その耐食性が大きく向上したことが報告さ れている ${ }^{29)}$ 。これは, 超はっ水性が表面に付与されたこと により, 空気が凹凸構造内に存在できるようになり, その空 気の存在が皮膜表面と水の接触面積を低減させ, 水分を介し た腐食反応が生じにくくなったためと報告されている ${ }^{15), 29) 。 ~}$ 本研究で作製した超はっ水皮膜に関しても, 同様の現象が生 じていた可能性が考えられるが, その詳細については今後の 検討課題である。

また，硝酸セリウム六水和物とフルオロアルキルシランを 原料に用いた 2 段階の浸漬処理で作製した超はっ水表面を有 する AZ31Bの $5 \mathrm{mass} \% \mathrm{NaCl}$ 水溶液中における分極曲線から 得られた $E_{\text {corr }}$ は- $1.35 \mathrm{~V} v \mathrm{~s} . \mathrm{Ag} / \mathrm{AgCl}, i_{\text {corr }}$ は $8.11 \times 10^{-7} \mathrm{~A} \cdot \mathrm{cm}^{-2}$ で あったことが報告されている ${ }^{30)}$ 。本研究で作製した超はっ 水皮膜と比較すると， $E_{\text {corr }}$ に関しては，本研究で作製した皮 膜の方が貴化しており，また， $i_{\text {corr }}$ の值も小さい。すなわち， 本研究で作製した皮膜の方が，2段階処理で作製したものよ りも優れた耐食性を示した。

超はっ水処理した $\mathrm{AZ} 31 \mathrm{~B}$ を $5 \mathrm{mass} \% \mathrm{NaCl}$ 水溶液に所定時 間浸漬後の耐食性を調べた。 $5 \mathrm{mass} \% \mathrm{NaCl}$ 水溶液中へ $1,6,12$, $24 \mathrm{~h}$ 浸漬させた後に得られた分極曲線を Fig. 5 (c), (d), (e), (f) にそれぞれ示す。超はっ水処理したAZ31Bの1, 6, 12, 24h 浸 漬後の $E_{\text {corr }}$ はそれぞれ $-0.25,-0.67,-0.38,-0.58 \mathrm{~V} v \mathrm{~s} . \mathrm{Ag} / \mathrm{AgCl}$, $i_{\text {corr }}$ は $8.81 \times 10^{-7}, 0.51 \times 10^{-6}, 0.85 \times 10^{-6}, 4.51 \times 10^{-6} \mathrm{~A} \cdot \mathrm{cm}^{-2}$ であっ た。塩水浸漬時間を長くすると， $i_{\text {corr }}$ は増加する傾向が見られ， 塩水浸漬により, 皮膜の耐食性が低下する傾向があったこと がわかる。一方, $E_{\text {corr }}$ は浸漬時間に伴い変化したが, 浸漬経 過時間との関連性はみられなかった。この $E_{\mathrm{corr}}$ の変化は, 浸 漬時間に依存して, 塩水と接する界面におけるマグネシウム 合金とセリウム系皮膜の存在割合が変化したためと考えられ る。しかし, 超はっ水処理したAZ31Bは, 塩水に浸漬した後 でも, 未処理のAZ31Bよりも貴な $E_{\text {corr }}$ と低い $i_{\text {corr }}$ を示してい ることから, 防食膜として効果があることがわかる。

\section{3 超はっ水処理したAZ31Bの塩水浸漬試験}

塩水環境下における超はっ水皮膜の腐食挙動を調べるた めに, 超はっ水処理を行った AZ31Bの塩水浸漬試験を行っ た。塩水浸漬前後の皮膜の変化や腐食生成物の確認を行j ために，浸漬前後の超はっ水処理したAZ31BのXRD測定を 行った。Fig. 6 に, 超はっ水処理したAZ31Bの塩水浸漬前後 のXRDパターンを示す。なお, Fig. 6 は, $\mathrm{Mg}$ の002反射の ピーク強度がすべて同じ值になるように再計算して得られ たものである。超はっ水処理したAZ31Bを3〜24h 浸漬させ たAZ31Bでは, $2 \theta=18.6,37.9,53.1,58.6$ 付近にピークが出現 した。これらのピークは, 水酸化マグネシウム $\left(\mathrm{Mg}(\mathrm{OH})_{2}\right)$ の001,011，012，110反射に帰属した。浸漬時間の増加に伴い, 
これらのピーク強度は増加した。マグネシウム合金を腐食環 境下に暴露すると，腐食生成物としての $\mathrm{Mg}(\mathrm{OH})_{2}$ が形成さ れることが知られている ${ }^{31)}$ 。このことから，塩水浸漬によ り， $\mathrm{Mg}(\mathrm{OH})_{2}$ が腐食生成物として形成されたといえる。ま た，浸漬時間の増加に伴いミリスチン酸由来のピーク強度は 低下し，24h後には消失した。このことは表面に存在してい たミリスチン酸が脱離したことを示す。

超はっ水処理を行ったAZ31Bの塩水浸漬試験前後の AZ31Bの外観写真と SEM 像を Fig. 7 に示す。なお，SEM像 に関しては，外観写真の中央部を撮影したものである。外観 写真から塩水浸漬前の超はっ水処理を行ったマグネシウム合 金には，灰色を呈する皮膜が生成したことがわかる。超はっ 水処理したAZ31Bを塩水に $1 \mathrm{~h}$ 浸漬させると, 皮膜表面の外 観が変化していたことから, 皮膜の構成物質の一部が脱離し たと考えられる。また, SEM像から，皮膜の表面状態がわ

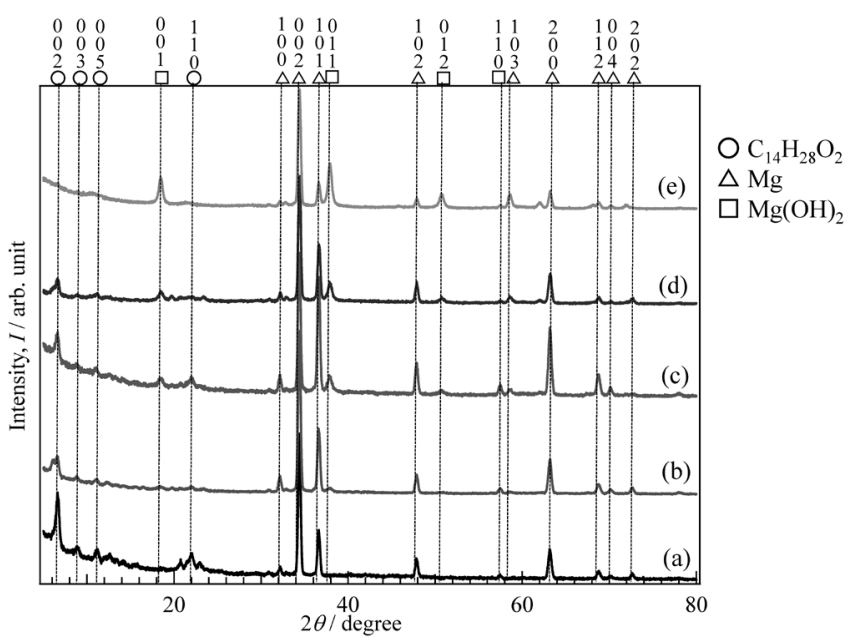

Fig. 6 XRD patterns of superhydrophobic AZ31B magnesium alloys (a) before and after immersion in 5 mass $\%$ $\mathrm{NaCl}$ aqueous solution for (b) 3, (c) 6, (d) 12, and (e) $24 \mathrm{~h}$.

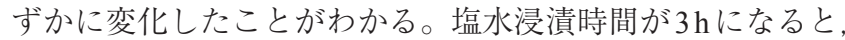
超はっ水皮膜が部分的に剥離した様子が観察された。また, SEM像から, 針状の細長い構造物の存在量が減少し, 新た な生成物が形成されたと考えられる。XRDの結果から，こ の生成物は $\mathrm{Mg}(\mathrm{OH})_{2}$ であると推察される。一方, ミリスチ ン酸の結晶性の固体層に起因するピークがXRDパターンで 観測されたことから，ミリスチン酸の結晶性の固体層は $3 \mathrm{~h}$ の塩水浸漬後の皮膜中に存在していたと考えられる。浸漬 時間を $6 \mathrm{~h}$ に増加させると, 外観写真やSEM像から, 暗灰色 の腐食生成物の形成量が増加したことがわかる。Fig. 6 の結 果より，ミリスチン酸の結晶性の固体層に起因するピーク 強度が低下し腐食生成物である $\mathrm{Mg}(\mathrm{OH})_{2}$ に起因するピーク 強度が増加したことから，ミリスチン酸の存在量が減少し $\mathrm{Mg}(\mathrm{OH})_{2}$ の形成量が増加したことがわかる。12hの浸漬後 では, XRDの結果より, 腐食生成物である $\mathrm{Mg}(\mathrm{OH})_{2}$ の形成 がより顕著になったことから, 超はっ水皮膜表面の固体ミリ スチン酸が脱離し，その存在量が減少したと考えられる。ま た，SEM-EDXの結果から，12h浸漬したAZ31Bの表面にお いて $\mathrm{Ce}$ と Oが検出されたことから, $\mathrm{CeO}_{2}$ あるいは $\mathrm{Ce}(\mathrm{OH})_{3}$

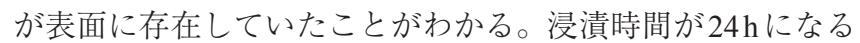
と, XRDパターンから, $\mathrm{Mg}(\mathrm{OH})_{2}$ に起因するピーク強度が 大きく増加し, 結晶性の固体層であるミリスチン酸に起因す るピークがほとんど検出されなかった。このことは, 結晶性 の固体層であるミリスチン酸が表面からほとんど脱離し，腐 食生成物である $\mathrm{Mg}(\mathrm{OH})_{2}$ の存在割合がより大きくなったこ とを示す。また，24h 浸漬後の表面においては，ミリスチン 酸の脱離に伴って皮膜中に含有された微量のセリウム系の酸 化物や水酸化物も消失したと推察されるが, SEM-EDXの結 果からCeがわずかに検出されたため, マグネシウム合金直 上に形成されたセリウム系の酸化物や水酸化物は残存してい たと考えられる。このマグネシウム合金上に形成されたセリ ウム系の酸化物や水酸化物が存在していたため, Fig. 5 に示 すように，24h浸漬後の超はっ水処理したAZ31Bは，未処理

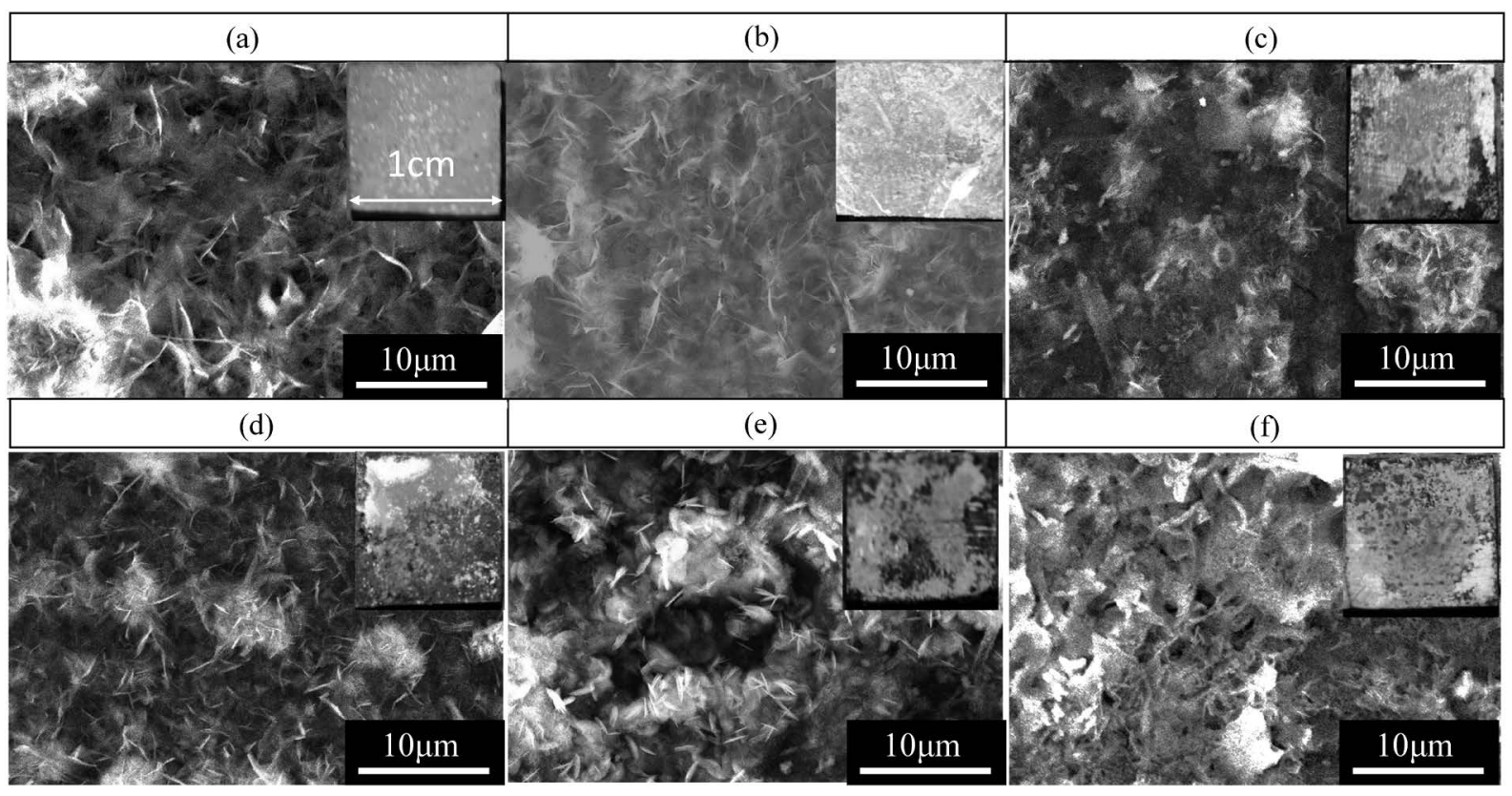

Fig. 7 SEM images of superhydrophobic AZ31B magnesium alloys (a) before and after immersion in 5 mass $\% \mathrm{NaCl}$ aqueous solution for (b) 1, (c) 3, (d) 6, (e) 12, and (f) 24h. Each inset shows low-magnification image. 


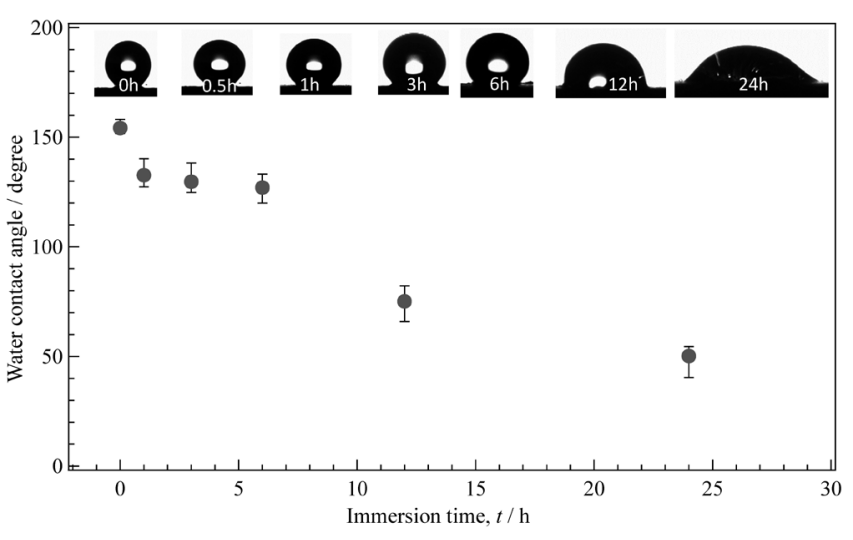

Fig. 8 Change in water contact angles with immersion time in $5 \mathrm{mass} \% \mathrm{NaCl}$ aqueous solution.

のAZ31Bよりも貴な $E_{\text {corr }}$ と低い $i_{\text {corr }}$ を示したと考えられる。

塩水浸漬時間と浸漬後の AZ31B 表面における静的接触角 の変化を Fig. 8 に示す。作製したAZ31Bの水溶液への浸漬時 間の増加に伴って, 処理した AZ31Bの水滴接触角が徐々に 低下した。1hの塩水浸漬により，水滴接触角は約 $130^{\circ}$ に低 下した。この接触角の低下の原因は, Fig. 7(b) のSEM像に 示したように, 皮膜の表面状態の変化によるものと考えら

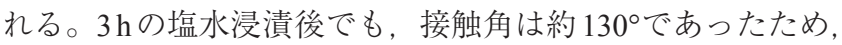
ミリスチン酸が表面に存在していたことがわかり，この結果 はFig. 7 のRDの結果と一致する。6hの塩水浸漬を行うと, その AZ31B 表面の水滴接触角の值は $3 \mathrm{~h}$ 浸漬のものよりもわ

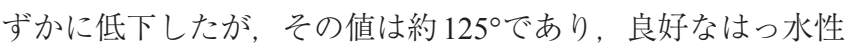
を示した。本研究において, 研磨後の比較的平滑なマグネシ ウム合金にミリスチン酸を被覆させた結果，その表面の水滴 接触角は $90^{\circ}$ 程度を示した。また，ミリスチン酸と同じ疎水 性官能基であるメチル基を表面に修飾した場合に得られる水 滴接触角の最大值は約 $110^{\circ}$ である ${ }^{32)}$ 。このため, 表面の水 滴接触角の值を $130^{\circ}$ 程度にするためには，凹凸構造の存在が 必要不可欠である。したがって, 塩水に $6 \mathrm{~h}$ 浸漬後の表面に は, 浸漬前の表面よりも表面積の小さいミリスチン酸由来の 凹凸構造が存在していたと推察される。浸漬時間が $12 \mathrm{~h}$ にな ると, その水滴接触角は約 $75^{\circ}$ になり, 親水性を示した。こ の接触角の值およびFig. 6 の結果から, 表面には, ミリスチ ン酸が存在していたことは明らかであるが, 上述のCassieBaxter式から考えると，ミリスチン酸の存在割合は低下した ことがわかる。しかし，空気とミリスチン酸からなる表面と してCassie-Baxter式を考慮すると，ミリスチン酸の面積分率 が低下すると空気の存在割合が増加し，接触角が向上するこ とになり，実験結果とは異なる。このため，ここでは，マグ ネシウム合金直上に形成されたセリウム系化合物の皮膜や腐 食生成物である $\mathrm{Mg}(\mathrm{OH})_{2}$ の存在も考慮する必要があり，こ れらの表面はいずれも親水性である ${ }^{17)}$ 。 $12 \mathrm{~h}$ の塩水浸漬後の 表面では，接触角の向上に寄与するミリスチン酸が脱離した ため，表面におけるミリスチン酸と空気で構成される領域の 面積分率が減少する。ミリスチン酸が脱離した領域には，親 水性のマグネシウム合金直上に形成されたセリウム系化合物 皮膜あるいは腐食生成物である $\mathrm{Mg}(\mathrm{OH})_{2}$ が存在すると考え られる。このため, 表面に拉けるセリウム系化合物皮膜ある いは $\mathrm{Mg}(\mathrm{OH})_{2}$ が存在する領域の面積分率が増加する。すな
わち, 接触角の向上に寄与するミリスチン酸と空気で構成さ れる領域の面積分率が減少し，同時に，親水性のセリウム系 化合物皮膜あるいは $\mathrm{Mg}(\mathrm{OH})_{2}$ が存在する領域の面積分率が 増加したため, 接触角が低下したと考えられる。浸漬時間 を $24 \mathrm{~h}$ にすると, 水滴接触角はさらに低下し, 約 $50^{\circ}$ になっ た。この值は, 硝酸セリウム水溶液を用いた2段階処理によ り AZ31B上に作製した超はっ水表面の AZ31Bを 5 mass\%の 塩水に $24 \mathrm{~h}$ 浸漬させた場合とほぼ同じ值であった ${ }^{21)}$ 。この報 告例においても, その表面は腐食生成物である $\mathrm{Mg}(\mathrm{OH})_{2}$ や $\mathrm{CeO}_{2}$ で被覆されていた。本研究の場合も同様に，表面が腐 食生成物の $\mathrm{Mg}(\mathrm{OH})_{2}$ やセリウム系の酸化物あるいは水酸化 物で覆われていたため, この表面の変化が水滴接触角を低下 させたと推察される。

これらの結果から, 超はっ水処理したAZ31Bの腐食過程 は, (1)塩水浸漬による結晶性固体層であるミリスチン酸の段 階的な脱離と凹凸構造の変化, および皮膜のクラック中へ の塩水の浸入, (2)はっ水性の低下および塩水との接触によ る AZ31Bの溶解と $\mathrm{Mg}(\mathrm{OH})_{2}$ の形成, (3)皮膜中に含まれるセ リウム系化合物の溶出, (4)皮膜中のセリウム系化合物の下に 存在した結晶性固体層であるミリスチン酸の段階的な脱離, (5)マグネシウム合金直上に形成されたセリウム系化合物の部 分的な露出と溶出, 6ミリスチン酸のさらなる脱離およびマ グネシウム合金直上に形成されたセリウム系化合物のさらな る露出と溶出, および溶出部における AZ31Bの溶解, (7) リウム系化合物の溶出部での $\mathrm{Mg}(\mathrm{OH})_{2}$ の形成, の順番で進 行したと考えられる。

\section{4. 結言}

硝酸セリウム六水和物 $\left(\mathrm{Ce}\left(\mathrm{NO}_{3}\right)_{3} \cdot 6 \mathrm{H}_{2} \mathrm{O}\right)$ とミリスチン 酸を含む水 /エ夕ノールの混合水溶液にマグネシウム合金 AZ31Bを 30 分間浸漬させることにより, 皮膜を AZ31B上に 形成した。その皮膜表面は, 水滴接触角が 150 以上の超はっ 水性を示した。作製した皮膜は，マグネシウム合金表面直上 のセリウム系皮膜と，その上の凹凸構造をもつ結晶性固体ミ リスチン酸皮膜で構成されていた。作製した超はっ水膜の耐 食性と劣化挙動を分極試験および塩水浸漬実験により評価し た。AZ31B上に超はっ水処理を施すことにより, 耐食性が 向上した。また，耐食性の向上に有効な要因は，ミリスチン 酸を主として形成された皮膜とセリウム系化合物からなる皮 膜の相乗効果であることを明らかにした。また，塩水浸漬 1 時間後に超はっ水性は損なわれたが，6時間浸漬までその表 面は高いはっ水性を示した。水滴接触角, XRD, SEM 観察 により, 超はっ水処理を施したAZ31Bの腐食過程を提示し た。

\section{謝 辞}

本研究の一部は, JSPS 科研費・基盤研究 A (16H02400) の援助のもとに遂行された。記して，謝意を表す。

\section{参 考 文 献}

1) 冨士明良：工業材料入門, 東京電機大学出版, (2009), 165-166.

2) R. Ambat, N. Aung and W. Zhou: Corros. Sci., 42 (2000), 1433-1455.

3) M. P. Staiger, A. M. Pietak, J. Huadmai and G. Dias: Biomater., 27 (2006), 1728-1734.

4) 秋山 茂, 上野英俊, 坂本 満, 平井寿敏, 北原 晃: まてり あ, 39 (2000)，72-74. 
5）金子純一，菅又 信：軽金属，54（2004），484-492.

6) 相田収平, 田辺 寛, 須貝裕之, 高野 格, 大貫秀樹, 小林 勝：軽金属, 50 (2000)，456-461.

7）幅崎浩樹：表面技術，67（2016），508-513.

8) A. R. Shashikala, R. Umarani, S. M. Mayanna and A. K. Sharma: Int. J. Electrochem. Sci., 3 (2008), 993-1004.

9) 西條充司，日野 実，平松 実，村上浩二，金谷輝人：表面技 術, 56 (2005), 547-551.

10）マグネシウム技術便覧編集委員会：マグネシウム技術便覧，日 本マグネシウム協会, (2000), 341-346.

11）石崎貴裕，高井 治：表面技術，64（2013），425-428.

12) 辻井 薰: 撥水 - 撥油の技術と材料, 監修 辻井 薰, 株式会 社シーエムシー出版, (2008), 3-13.

13) T. Ishizaki and M. Sakamoto: Langmuir, 27 (2011), 2375-2381.

14) K. Liu, M. Zhang, J. Zhai, J. Wang and L. Jiang: Appl. Phys. Lett., 92 (2008), 183103-1-183103-3.

15) T. Ishizaki, S. Kumagai, M. Tsunakawa, T. Furukawa and K. Nakamura: Mater. Lett., 193 (2017), 42-45.

16) B. R. W. Hinton: Handbook on the Physics and Chemistry of Rare Earths, ed. by K. A. Gschneidner, Jr. and L. Eyring, Elsevier Science B.V., (1994), 29-92.

17) T. Ishizaki and N. Saito: Langmuir, 26 (2010), 9749-9755.

18) R. Olbrich, G. E. Murgida, V. Ferrari, C. Barth, A. M. Llois, M. Reichling and M. V. Ganduglia-Pirovano: J. Phys. Chem. C, 121 (2017), 6844-6851.

19) H. Pinto, M. N. Mintz, M. Melamud and H. Shaked: Phys. Lett. A, 88 (1982), 81-83.
20) N. V. Skorodumova, R. Ahuja, S. I. Simak, I. A. Abrikosov, B. Johansson and B. I. Lundqvist: Phys. Rev. B, 64 (2001), 11510801-115108-09.

21) L. Eyring: Synthesis of Lanthanide and Actinide Compounds, eds. by G. Meyer and L. R. Morss, Springer, (1991), 187-224.

22) 辻井 薰: 撥水 - 撥油の技術と材料, 監修 辻井 薰, 株式会 社シーエムシー出版, (2008), 207-221

23) ICDD-PDF No. 00-008-0786, (1955).

24) R. Scheu, Y. X. Chen, M. Subinya and S. Roke: JACS, 135 (2013), 19330-19335.

25) 稲岡紀子生, 友田 進: 弓削商船高等専門学校紀要, 23 (2001), $27-32$.

26) A. B. D. Cassie and S. Baxter: Trans. Faraday Soc., 40 (1944), 546550.

27) Z. Yoshimitsu, A. Nakajima, T. Watanabe and K. Hashimoto: Langmuir, 18 (2002), 5818-5822.

28) M. Miwa, A. Nakajima, A. Fujishima, K. Hashimoto and T. Watanabe: Langmuir, 16 (2000), 5754-5760.

29) T. Ishizaki, J. Hieda, N. Saito, N. Saito and O. Takai: Electrochim. Acta, 55 (2010), 7094-7101.

30) T. Ishizaki, M. Okido, Y. Masuda, N. Saito and M. Sakamoto: Langmuir, 27 (2011), 4780-4788.

31) T. Ishizaki, R. Kudo, T. Omi, K. Teshima, T. Sonoda, I. Shigematsu and M. Sakamoto: Mater. Lett., 68 (2012), 122-125.

32) C. D. Bain, E. B. Troughton, Y. T. Tao, J. Evall, G. M. Whitesides and R. G. Nuzzo: J. Am. Chem. Soc., 111 (1989), 321-335. 